\title{
Susceptibility to diabetes is widely distributed in normal class II" haplotype rats
}

\author{
K. E. Ellerman, A.A. Like \\ Department of Pathology, University of Massachusetts Medical School, Worcester, Mass., USA
}

\begin{abstract}
Aims/hypothesis. We did experiments to explore the pathways putatively leading to Type I (insulin-dependent) diabetes mellitus, and their association with the MHC locus, the major genetic determinant of disease susceptibility.

Methods. Normal MHC congenic rat strains that do not spontaneously develop diabetes or any other autoimmune syndrome were injected with the interferon-alpha inducer polyinosinic-polycytidylic acid (Poly IC).

Results. Insulitis and diabetes developed only in strains expressing Class $\mathrm{II}^{\mathrm{u}}$ genes and was independent of the Class I haplotype. Poly IC induced islet cell Class I hyperexpression, up regulation of pancreatic endothelial intercellular adhesion molecule-1 and vascular adhesion molecule- 1 and a T-cell and macrophage infiltration of the pancreatic interstitium
\end{abstract}

in all rat strains studied, including diabetes-resistant strains. Poly IC also induced the generation of diabetes-transferring spleen cells in most Class $\mathrm{II}^{\mathrm{u}}$ haplotype rats, including the diabetes-resistant $W F$ rat. Conclusion/Interpretation. The minimum requirements for autoimmune diabetes development in the rat include: $R T 1$ Class $\mathrm{II}^{\mathrm{u}}$ genes, a T-cell repertoire containing beta-cell autoreactive T cells and a triggering event which breaks tolerance by the local up regulation of pancreatic endothelial adhesion receptors. Even when all of the minimum requirements have, however, been met, most Class II $^{\mathrm{u}}$ rats do not develop diabetes in response to autoimmune stimuli. It is clear, nonetheless, that susceptibility to diabetes is widely distributed in the $R T 1^{u}$ rat. [Diabetologia (2000) 43: 890-898]

Keywords Autoimmunity, $B B$ rat, MHC Class II, adhesion molecules.
Type I (insulin-dependent) diabetes mellitus is a $\mathrm{T}$ cell-mediated disease of polygenic origin in man, mouse and rat, which is strongly associated with MHC Class II susceptibility alleles [1-3]. In the rat, spontaneous autoimmune diabetes has been reported

Received: 8 February 2000 and in revised form: 27 March 2000

Corresponding author: K. Ellerman, PhD., Torrey Pines Institute for Molecular Studies, 3550 General Atomics Court, San Diego, CA 92121, USA

Abbreviations: DP, diabetes-prone; DR, diabetes-resistant; IFN- $\alpha$, interferon-alpha; KRV, Kilham rat virus; mAB, monoclonal antibody; Poly IC, polyinosinic-polycytidylic acid; ICAM, intercellular adhesion molecule-1; VCAM-1, vascular adhesion molecule-1 only in the $B B /$ Wor diabetes-prone (DP) [4-5] and LETL strains [6-7], who share the $R T 1^{u}$ MHC haplotype. Experimental infection with Kilham rat virus (KRV) will induce Type I diabetes in $B B / W o r$ diabetes-resistant (DR) [8] and LEW1.WR1 [9] rats, who share Class I $A^{u}$ and Class II $B / D^{u}$ alleles. The $W A G$ (A. Like, unpublished observation) and $W F$ [8] rats, who also bear the $R T 1^{u}$ haplotype, do not, however, develop insulitis or diabetes after infection with KRV. Further PVG.RTI ${ }^{u}$ rats develop an autoimmune diabetes after thymectomy and a series of $\gamma$-irradiations [10] and after treatment with KRV and Poly IC [9]. Finally, the PVG.RT1 ${ }^{c}$ rat has been reported to develop Type I diabetes, also after thymectomy and irradiation [11]. All these studies suggest that diabetes susceptibility genes are widely distribut- 
Table 1. Poly IC induces autoimmune diabetes in non-diabetes prone rat strains

\begin{tabular}{llcll}
\hline Strain & $\begin{array}{l}\mathrm{RT} 1 \\
\mathrm{~A}, \mathrm{~B} / \mathrm{D}, \mathrm{C}\end{array}$ & Diabetes & Insulitis & $\begin{array}{l}\text { Mean time } \\
\text { (days) to } \\
\text { diabetes }\end{array}$ \\
\hline LEW1.WR1 & $\mathrm{u} / \mathrm{u} / \mathrm{a}$ & $22 / 22$ & $22 / 22$ & 5 \\
$P V G . R T 1^{\mathrm{u}}$ & $\mathrm{u} / \mathrm{u} / \mathrm{u}$ & $26 / 30$ & $25 / 28$ & 5 \\
$P V G . R 8$ & $\mathrm{a} / \mathrm{u} / \mathrm{u}$ & $2 / 10$ & $2 / 10$ & 8 \\
& & $6 / 9^{\mathrm{a}}$ & $6 / 9^{\mathrm{a}}$ & \\
PVG.R23 & $\mathrm{u} / \mathrm{a} / \mathrm{a}$ & $0 / 10$ & $0 / 10$ & - \\
& & $0 / 10^{\mathrm{a}}$ & $0 / 10^{\mathrm{a}}$ & \\
$P V G . R T 1^{\mathrm{c}}$ & $\mathrm{c} / \mathrm{c} / \mathrm{c}$ & $0 / 12$ & $0 / 12$ & - \\
& & $0 / 5^{\mathrm{b}}$ & $0 / 5^{\mathrm{b}}$ & - \\
WF & & $0 / 7^{\mathrm{a}}$ & $0 / 7^{\mathrm{a}}$ & - \\
& $\mathrm{u} / \mathrm{u} / \mathrm{u}$ & $0 / 7$ & $0 / 7$ & - \\
LOU & & $1 / 15^{\mathrm{a}}$ & $1 / 15^{\mathrm{a}}$ & $5^{\mathrm{a}}$ \\
$W A G$ & $\mathrm{u} / \mathrm{u} / \mathrm{u}$ & $0 / 6$ & $0 / 6$ & - \\
\hline Rats $W e r e \mathrm{n}$ & $\mathrm{u} / \mathrm{u} / \mathrm{u}$ & $1 / 9$ & $2 / 8$ & 0 \\
\hline
\end{tabular}

Rats were injected with $7.5 \mu \mathrm{g} / \mathrm{g}$ body weight Poly IC, 5 days a week for 2 weeks (unless otherwise noted). The mean time to diabetes was calculated from the last day of Poly IC injections to the first day of glycosuria and hyperglycaemia (blood glucose $\geq 13.8 \mathrm{mmol} / \mathrm{l})$. 0/9 PBS-injected $P V G . R T 1^{\mathrm{u}}$, 0/5 PBS-injected $L E W 1$.WR1 and 0/6 PBS-injected PVG.R8 rats developed insulitis or diabetes. ${ }^{\text {a }} 3$ weeks of Poly IC injections at $7.5 \mu \mathrm{g} / \mathrm{g}$ body weight, ${ }^{\mathrm{b}} 2$ weeks of Poly IC injections at $10 \mu \mathrm{g} / \mathrm{g}$ body weight

ed in the rat and susceptibility could map to regions outside the MHC. To explore the pathways which lead to autoimmunity as well as their association with the MHC, we made use of the interferon- $\alpha$ (IFN- $\alpha$ )-inducer, Poly IC, and a series of $R T 1^{u}$ congenic rat strains, with differing constellations of Class I and Class II genes. None of the $R T 1$ congenics are predisposed to spontaneous autoimmunity or have mutant $R T 1$ alleles.

Polyinosinic-polycytidylic acid (Poly IC) is a synthetic double-stranded RNA which induces brisk production of Type I interferons in vivo [12-13]. Poly IC has traditionally been used as an experimental surrogate for viral infections, which also induce the synthesis of Type I interferons ( $\alpha$ and $\beta$ ) [14]. Doublestranded RNA is thought to be the interferon-inducing intermediate produced during viral infection [12]. Finally, injections of Poly IC accelerate the onset of Type I diabetes in the $B B-D P$ rat [15], and induce diabetes in the coisogenic BB diabetes-resistant rat [16].

\section{Materials and methods}

Animals. Inbred BB-DP/Wor, LEW1.WR1, PVG.RT1 ${ }^{u}$, PVG.R8, PVG.R23, WAG and athymic WAG/rnu rats were raised at the University of Massachusetts Medical Center under viral antibody-free conditions. Inbred $W F, L O U$, and $P V G . R T 1^{c}$ rats were obtained from Harlan Sprague Dawley (Indianapolis, Ind., USA). All animal studies were approved by the Institutional Animal Care and Use Committee.
Treatment with Poly IC. Male and female rats, 4-5 weeks of age, were used in all experiments. Rats were injected i.p. with $7.5 \mu \mathrm{g} / \mathrm{g}$ body weight Poly IC (P1530, Sigma, St. Louis, Mo., USA), 5 days/week (Monday to Friday) for 2 weeks (or 3 weeks as noted in Table 1). Other than the induction of Type I diabetes in susceptible strains, no morbidity or mortality was associated with this dose of Poly IC. Poly IC was dissolved in PBS. Control rats were injected with PBS.

Detection of diabetes. After 2 weeks of Poly IC treatment, animals were tested for glycosuria three times weekly for 3 weeks. Diabetes was diagnosed on the basis of glycosuria (TesTape, Lilly, Indianapolis, Ind., USA) and a blood glucose concentration of $13.8 \mathrm{mmol} / \mathrm{l}$ or more in tail blood (Beckman Glucose Analyzer II, Beckman, Fullerton, Calif., USA). Diabetic rats were killed on the day of detection, and the non-diabetic rats were killed at the end of the 3 -week monitoring period.

Morphologic studies. Pancreata and thyroids were fixed in Bouins solution and embedded in paraffin. Haematoxylin-eosin stained sections were examined for the presence of lymphocytic insulitis and thyroiditis. Tissues were removed from diabetic rats on the day of detection, and from the non-diabetic rats at the conclusion of the study.

Con A-activation of spleen cells. Spleens were harvested after 2 weeks of Poly IC or PBS injections, processed into single cell suspensions and cultured at $5 \times 10^{6}$ cells $/ \mathrm{ml}$ in RPMI 1640, $2 \mathrm{mmol} / 1 \mathrm{~L}$-glutamine, $10 \mathrm{mmol} / \mathrm{l} \mathrm{HEPES}, 5 \times 10^{-5} \mathrm{~mol} / \mathrm{l}$ 2-mercaptoethanol, $5 \%$ FCS (Hyclone, Logan Utah, USA), and $4 \mu \mathrm{g} / \mathrm{ml}$ Con A (ICN, Costa Mesa, Calif., USA) for 3 days at $37^{\circ} \mathrm{C}$ and $6.5 \% \mathrm{CO}_{2}$. Activated cells were washed three times in RPMI before injection.

Adoptive transfer of diabetes. One spleen equivalent of Con Aactivated spleen cells was injected i.p. into 21 to 25 -day-old syngeneic, $B B-D P / W o r$ or $W A G / r n u$ recipients. Injected rats were monitored for 3 weeks for the development of glycosuria and hyperglycaemia (blood glucose $\geq 13.8 \mathrm{mmol} / \mathrm{l}$ ). Diabetic rats were killed on the day of detection and the non-diabetic rats at the end of the 3 -week monitoring period. All recipient rats were examined for insulitis.

Monoclonal antibodies $(m A B s)$. The mouse hybridoma cell lines OX-8 (which binds rat CD $8 \alpha$-chain), OX-18 (which binds non-polymorphic RT1A Class I molecules), OX-19 (which binds all rat T cells), OX-42 (which binds rat CD11 b on monocytes and macrophages), 1A29 [which binds rat intercellular adhesion molecule-1 (ICAM-1) (CD54)], and 341 (which binds rat $\mathrm{CD} 8 \beta$-chain expressed on $\mathrm{CD}^{+} \mathrm{T}$ cells but not on $\mathrm{CD} 4^{+} \mathrm{T}$ cells or NK cells ) were used to produce tissue culture supernatants for immunostaining. Culture supernatants were used undiluted. The ED-1 antibody (Serotec, Raleigh, N.C., USA) reacts with most rat macrophages and some dendritic cells; ED-1 ascites was used at a dilution of 1:100. The rat vascular cell all adhesion molecule 1 (VCAM-1) (CD106) antibody (Babco, Berkeley, Calif., USA) was used at a dilution of 1:300. Antibodies were diluted in PBS-1\% horse serum (HS).

Immunostaining. Pancreata were immersed in ornithine carbamoyltransferase (OCT) embedding medium and snap-frozen in liquid nitrogen-cooled isopentane before sectioning. Cryostat sections $(5 \mu)$ were mounted on slides, fixed in acetone at $-20^{\circ} \mathrm{C}$, and stored at $-20^{\circ} \mathrm{C}$. For staining, slides were immersed in acetone (10 min), air-dried, washed in PBS-1\% horse serum and then immersed in $3 \% \mathrm{H}_{2} \mathrm{O}_{2}-1 \%$ BSA for $10 \mathrm{~min}$. Slides were sequentially blocked with $0.5 \%$ avidin 


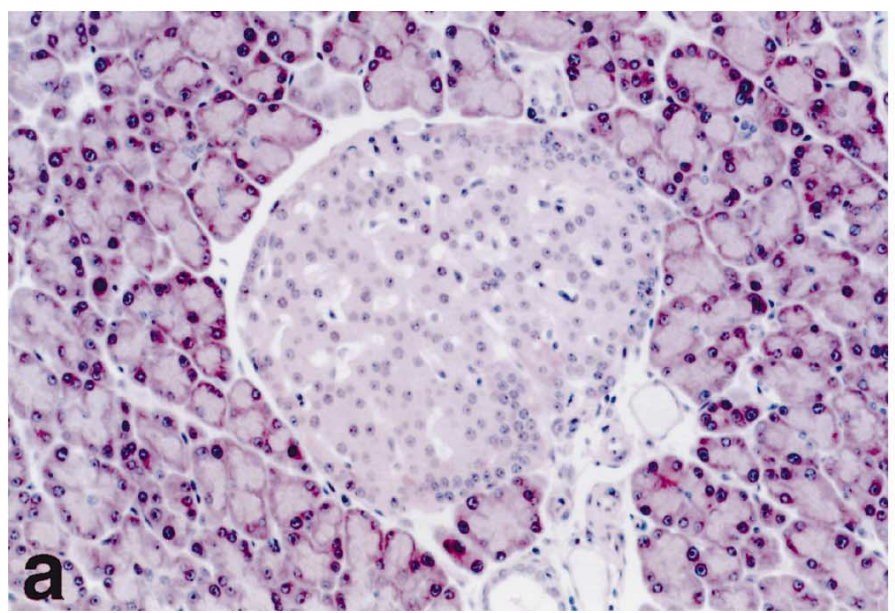

Fig.1 A, B. Class $\mathrm{II}^{\mathrm{u}}$ but not Class $\mathrm{II}^{\mathrm{c}}$ rats develop insulitis and diabetes after Poly IC injections. Illustrated are pancreatic sections of Poly IC-treated rats stained with haemotoxylin and eosin. A The diabetes-resistant $\mathrm{PVG}^{\mathrm{c}}$ rat was treated for 3 weeks with Poly IC and followed for another 3 weeks for the development of hyperglycaemia. There is no evidence of insulitis. B The Class $I I^{u}$ LEW1.WR1 rat was treated for 2 weeks with Poly IC: hyperglycaemia developed 7days after the last injection. Lymphocytic insulitis and beta-cell destruction are present

and $0.1 \%$ biotin for $20 \mathrm{~min}$ to quench endogenous biotin-reactive sites. Sections were incubated with antibody for $30 \mathrm{~min}$., followed by biotinylated horse anti-mouse IgG (1:100) (Vector Labs, Burlingame, Calif., USA) (30 min) and avidin-horseradish peroxidase (1:200) (Vector Labs) for $30 \mathrm{~min}$. Reaction product was developed with diaminobenzidine $(2 \mathrm{mg} / \mathrm{ml})$. The counterstain was methylene blue. Staining procedures were done at room temperature.

Scoring. Specimens were scored by two independent observers. Syngeneic rats injected with PBS served as baseline controls for immunostaining. The scoring system for endothelial adhesion receptors was $0=$ no staining or constitutive levels (as seen in controls), $1+=$ increased staining compared with PBS controls, $2+=$ moderately intense staining of many vessels, $3+=$ intense staining that is widespread. Scores for T cells and macrophages were based on the degree of infiltration of positive cells; $1+=$ sparse infiltration of positive cells, $2+=$ moderate cellular infiltration, $3+=$ extensive infiltrates of positive cells.

\section{Results}

Autoimmune diabetes is induced in many non-diabetes prone rat strains by Poly IC treatment. To explore the spectrum of diabetes susceptibility in normal rats, inbred and MHC congenic rat strains were injected with Poly IC. Injections were given 5 days a week for 2 weeks, and in some rats, 3 weeks. Controls were injected with diluent (PBS). Injected animals were then followed for 3 weeks for the development

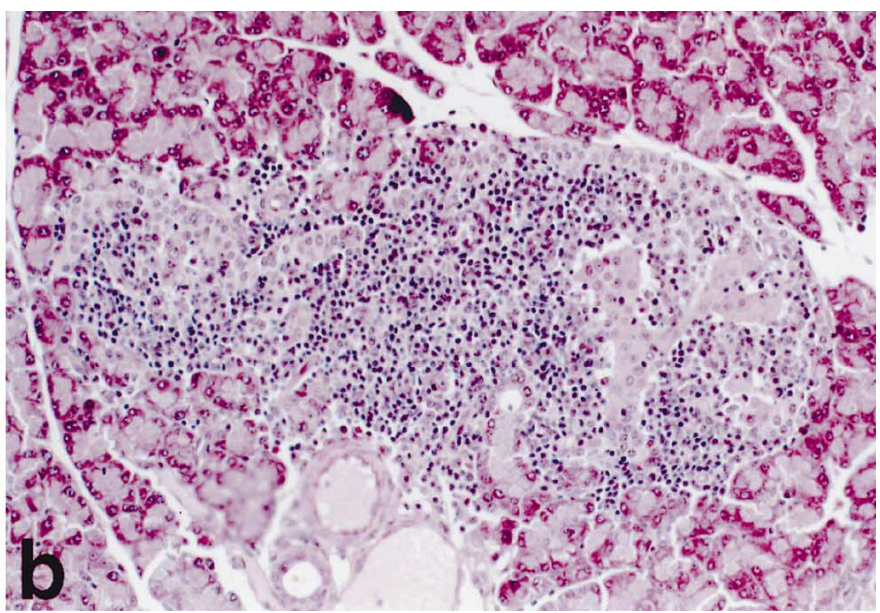

of glycosuria and hyperglycaemia (blood glucose $\geq 13.8 \mathrm{mmol} / \mathrm{l}$ ). The rat $\mathrm{MHC}$ is denoted as RT1, where $\mathrm{A}$ and $\mathrm{C}$ are Class I loci and $\mathrm{B} / \mathrm{D}$ are Class II loci.

Treatment with Poly IC induces autoimmune diabetes in normal LEW1.WR1, PVG.RT1 ${ }^{u}, P V G . R 8$, $W F$, and $W A G$ strains (Table 1 ). The incidence of insulitis and diabetes varied between strains: $100 \%$ of LEW1.WR1 rats developed diabetes after 2 weeks of Poly IC injections, whereas only $1 / 15 W F$ rats became diabetic after 3 weeks of Poly IC. Insulitis and diabetes appeared only in strains expressing Class $\mathrm{II}^{\mathrm{u}}$ genes. The development of insulitis and diabetes was independent of the Class I haplotype, occurring in both LEW1.WR1 (Class I $\mathrm{A}^{\mathrm{u}} \mathrm{C}^{\mathrm{a}}$ ) and PVG.R8 (Class I $\mathrm{A}^{\mathrm{a}} \mathrm{C}^{\mathrm{u}}$ ) strains, which are concordant at the Class II loci, but discordant at both Class I loci. Furthermore, Class II ${ }^{\mathrm{a}} P V G . R 23$ rats share the Class I $A^{u}$ allele with $B B-D P, L E W 1$.WR1 and $P V G . R T 1^{u}$ rats but do not develop diabetes in response to Poly IC. Thus, these studies do not show a requirement for a specific Class $\mathrm{I}^{\mathrm{u}}$ allele in the diabetogenic response to Poly IC. Diabetes occurred with equal frequency in both males and females.

Lymphocytic insulitis and selective beta-cell destruction (Fig. 1) always accompanied diabetes. Diabetic rats had residual islet structures comprised only of non-beta endocrine cells (data not shown). The inflammatory cells infiltrating the islets of Langerhans were predominantly of the monocytemacrophage lineage, with $\mathrm{CD} 8^{+} \mathrm{T}$ cells making up the majority of insulitic T cells (Fig. 2). Thyroiditis occasionally accompanies spontaneous diabetes in the $B B$ rat [17] but was not observed in any of the Poly IC-injected rats.

Poly IC treatment leads to the generation of diabetestransferring spleen cells. Adoptive transfer studies were done to assess the role of T cells in Poly IC induced diabetes. Con A-activated spleen cells from spontaneously diabetic $B B$ rats transfer diabetes into syngeneic as well as Class II-compatible recipients 


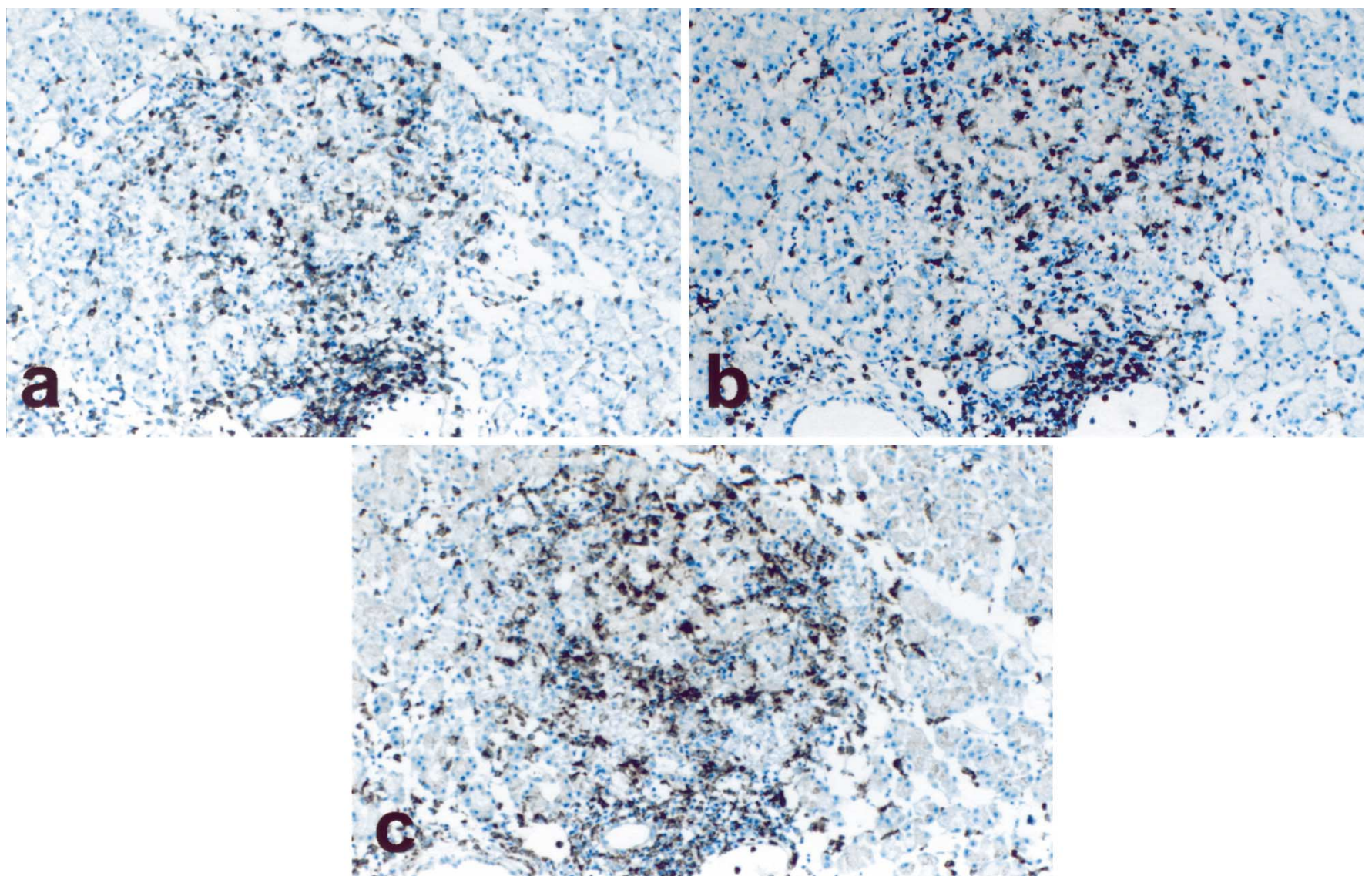

Fig. 2 A-C. Monocyte/macrophages and T cells infiltrate the islets of Langerhans in diabetes-susceptible Class II $^{\mathrm{u}}$ rats treated with Poly IC. Illustrated are immunoperoxidase-stained pancreatic sections of a $L E W 1$.WR1 rat treated for 9 days with Poly IC. Sections are stained with $\mathrm{mABs}$ directed against (A) OX-19 (pan T), (B) 341 (CD8 $\beta$-chain) and (C) ED-1 (monocytes, macrophages and dendritic cells). $\mathrm{CD}^{+} \mathrm{T}$ cells make up the majority of islet-infiltrating lymphocytes

Table 2. Adoptive transfer of diabetes by Con A-activated spleen cells from Poly IC-treated rats

\begin{tabular}{llll}
\hline $\mathrm{RT} 1$ & Donor & Recipient & $\begin{array}{l}\text { Incidence of } \\
\text { diabetes }\end{array}$ \\
\hline $\mathrm{u} / \mathrm{u} / \mathrm{a}$ & LEW1.WR1 & LEW1.WR1 & $17 / 17$ \\
$\mathrm{u} / \mathrm{u} / \mathrm{u}$ & $P V G . R T 1^{\mathrm{u}}$ & $P V G . R T 1^{\mathrm{u}}$ & $7 / 7$ \\
$\mathrm{u} / \mathrm{a} / \mathrm{a}$ & $P V G . R 23$ & $P V G . R 23$ & $0 / 5$ \\
$\mathrm{c} / \mathrm{c} / \mathrm{c}$ & $P V G . R T 1^{\mathrm{c}}$ & $P V G . R T 1^{\mathrm{c}}$ & $0 / 10$ \\
$\mathrm{u} / \mathrm{u} / \mathrm{u}$ & $W F$ & $D P / B B$ & $12 / 21$ \\
$\mathrm{u} / \mathrm{u} / \mathrm{u}$ & $W F$ & $W F$ & $0 / 10$ \\
$\mathrm{u} / \mathrm{u} / \mathrm{u}$ & $W F$ & $W A G / r n u$ & $4 / 6$ \\
$\mathrm{u} / \mathrm{u} / \mathrm{u}$ & $L O U$ & $D P / B B$ & $0 / 5$ \\
$\mathrm{u} / \mathrm{u} / \mathrm{u}$ & $W A G$ & $W A G / r n u$ & $4 / 6$ \\
\hline
\end{tabular}

After 2 weeks of Poly IC injections, spleen cells were Con Aactivated in vitro and one spleen equivalent of activated cells was injected i.p. into 21 to 25 -day-old syngeneic, $B B /$ Wor diabetes-prone or $W A G / r n u$ recipients. Blast transformation and cell viability (always $>90 \%$ by trypan blue) were not different between rat strains. Cell recipients were followed for 3 weeks for the development of glycosuria and hyperglycaemia (blood glucose $\geq 13.8 \mathrm{mmol} / \mathrm{l}$ )
[18]. Adoptive transfer of diabetes by Con A-activated spleen cells provides strong support for a T cellmediated pathogenesis.

After 2 weeks of Poly IC or PBS injections, spleen cells were harvested and Con A activated in vitro. Poly IC-injected rats were not diabetic at the time of spleen harvesting. Activated cells were injected into naive syngeneic, $B B-D P / W o r$, or $W A G / r n u$ recipients. The data in Table 2 demonstrate that Poly IC injections induce the generation of diabetes-transferring spleen cells in Class $I I^{u}$ LEW1.WR1, PVG.RT1 ${ }^{u}$, $W F$ and $W A G$ rats. Con A-activated spleen cells from Poly IC-injected $P V G . R 23, P V G . R T 1^{c}$ and $L O U$ rats did not transfer insulitis or diabetes. Finally, Con Aactivated peripancreatic lymph node cells from Poly IC-treated $L E W 1$.WR1 rats transferred diabetes into 5 of 6 naive $L E W 1$.WR1 recipients (data not shown), also suggesting a role for T cells in disease transfer.

Surprisingly, Con A-activated $W F$ spleen cells transferred insulitis and diabetes into $B B-D P$ and $W A G / r n u$ rats but not into $W F$ rats. When pooled Con A-activated $W F$ spleen cells were simultaneously transferred into both $B B-D P$ and $W F$ rats, only $B B-D P$ recipients developed insulitis or diabetes. Thus, $W F$ rats have diabetogenic T cells but those cells are ineffective in $W F$ (but not $B B-D P$ or $W A G /$ $r n u)$ hosts. $W F$ rats do not, however, lack beta-cell target antigens because Con A-activated spleen cells 

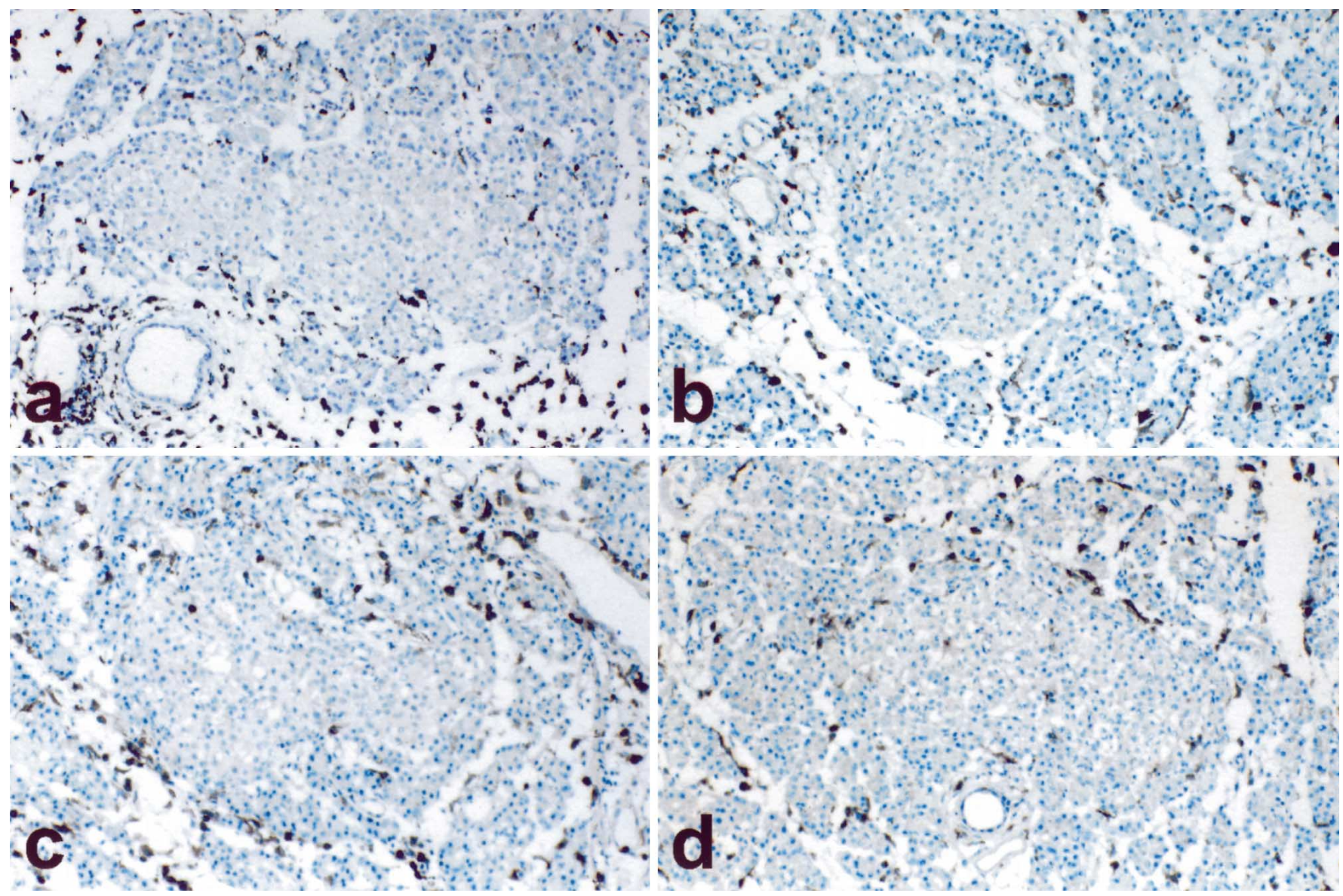

Fig.3 A-C. Monocyte/macrophages and $\mathrm{CD}^{+} \mathrm{T}$ cells do not infiltrate into the islets of Langerhans in diabetes-resistant rats treated with Poly IC. Illustrated are immunoperoxidasestained pancreatic sections of Poly IC-treated rats. Sections are stained with $\mathrm{mABs}$ directed against $\mathrm{CD} 8(\mathrm{OX}-8)(\mathbf{B}$ and C) and ED-1 (A and D). Islets from $\operatorname{PVG}^{\mathrm{c}}(\mathbf{A}$ and $\mathbf{B})$ and $W F$ $(\mathbf{C}$ and $\mathbf{D})$ rats are shown. Peri-insulitis but not intra-islet infiltrations are seen in diabetes-resistant strains. The $W F$ rat was injected with Poly IC for 8 days and the $P V G^{c}$ rat for 13 days

from diabetic $B B-D P[19]$ or $K R V$-infected $B B-D R$ [9] rats will transfer diabetes into $W F$ recipients.

Poly IC injections up-regulate islet cell Class I and pancreatic endothelial ICAM-1 and VCAM-1 expression. To examine the proinflammatory changes which occur before the development of insulitis and diabetes, pancreatic tissues were removed after 5 and 8 days of injections. After 8 days of Poly IC, insulitis is occasionally present in diabetes-susceptible strains but is never present in diabetes-resistant strains. Immunoperoxidase stains were done on cryostat sections using monoclonal antibodies directed against rat Class I antigens, ICAM-1, VCAM-1, CD8, pan T cells and macrophage/dendritic cell lineages. Syngeneic PBS-injected rats served as baseline controls for immunostaining.
Table 3. The effect of 8 days of Poly IC injections on pancreatic morphology

\begin{tabular}{lllll}
\hline Strain & $\begin{array}{l}\text { Islet/ } \\
\text { exocrine } \\
\text { Class I }\end{array}$ & $\begin{array}{l}\text { Endothelial } \\
\text { VCAM-1 }\end{array}$ & $\begin{array}{l}\text { Endothelial } \\
\text { ICAM-1 }\end{array}$ & $\begin{array}{l}\text { Infiltrating } \\
\text { macs/ } \\
\mathrm{CD} 8^{+} \mathrm{T}\end{array}$ \\
\hline LEW1.WR1 & $3^{+} / 3^{+}$ & $2^{+}$ & $2^{+}$ & $3^{+} / 2^{+}$ \\
PVG.RT1 & $3^{+} / 3^{+}$ & $2^{+}$ & $2^{+}$ & $3^{+} / 2^{+}$ \\
PVG.R23 & $3^{+} / 3^{+}$ & $1.5^{+}$ & $2^{+}$ & $3^{+} / 1^{+}$ \\
$P V G . R T 1^{\mathrm{c}}$ & $3^{+} / 3^{+}$ & $1.5^{+}$ & $2^{+}$ & $3^{+} / 1^{+}$ \\
WF & $3^{+} / 3^{+}$ & $2^{+}$ & $2^{+}$ & $3^{+} / 2^{+}$ \\
LOU & $3^{+} / 3^{+}$ & $2^{+}$ & $3^{+}$ & $3^{+} / 3^{+}$
\end{tabular}

PBS-injected syngeneic rats served as base-line controls for immunostaining. Rats $(n=3-9)$ from each strain were analysed. Scoring was done on a scale of 0-3: $0=$ constitutive levels (as seen in controls); $1+=$ increased staining compared to controls; $2+=$ moderately intense staining or cellular infiltration; $3+=$ intense staining or extensive cellular infiltration. The mean value for each strain is given. The mononuclear cell infiltration scored in this table is restricted to the pancreatic interstitium

Poly IC injections given for 8 days induce islet and exocrine cell Class I hyperexpression (data not shown), up regulation of endothelial ICAM-1 and VCAM-1 and a concomitant $\mathrm{T}$ cell and macrophage infiltration of the pancreatic interstitium in all rat strains studied, including diabetes-resistant rats (Ta- 


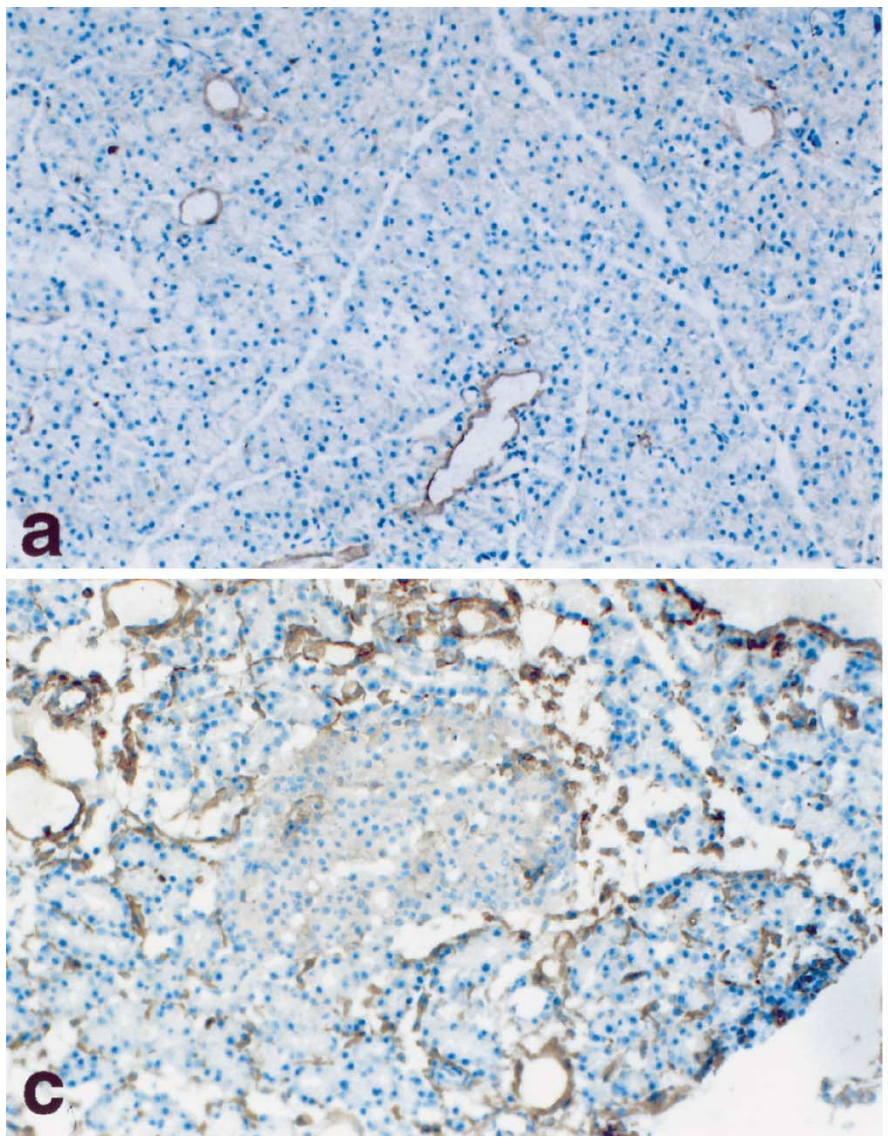

Fig.4A-C. Poly IC-treatment increases the numbers of ICAM- $1^{+}$endothelial cells in both diabetes-susceptible and resistant rat strains. The intensity of ICAM-1 staining is also increased. Pictured are pancreatic sections stained by the immunoperoxidase method for ICAM-1 (CD54). A A control LOU rat injected with PBS for 8 days: endothelial cells exhibit constitutive levels of immunoreactive ICAM-1. B A diabetesresistant $L O U$ rat injected with Poly IC for 8 days. C A diabetes-susceptible $P V G^{u}$ rat injected with Poly IC for 8 days. The induction of endothelial ICAM-1 is thus not sufficient for the development of Type I diabetes

ble 3, Fig. 2-5). As assessed by an examination of pancreatic histology after 5 and 8 days of Poly IC, the expression of islet cell Class I and endothelial VCAM-1 and the numbers of infiltrating macrophages increased progressively over time. Endothelial ICAM-1 was up regulated to the maximum after 5 days of Poly IC injections, with sustained high expression still seen after 8 days. The kinetics of Class I, ICAM-1 and VCAM-1 up regulation and macrophage infiltration were identical in all rat strains. The numbers of infiltrating $\mathrm{T}$ cells varied, however, between strains but did not correlate with susceptibility or resistance to disease induction. Finally, although the number of infiltrating $\mathrm{CD}^{+} \mathrm{T}$ cells appeared to approach the number of $\mathrm{OX}-19^{+}$(pan) $\mathrm{T}$ cells (Fig.2), we cannot rule out the presence of a minor

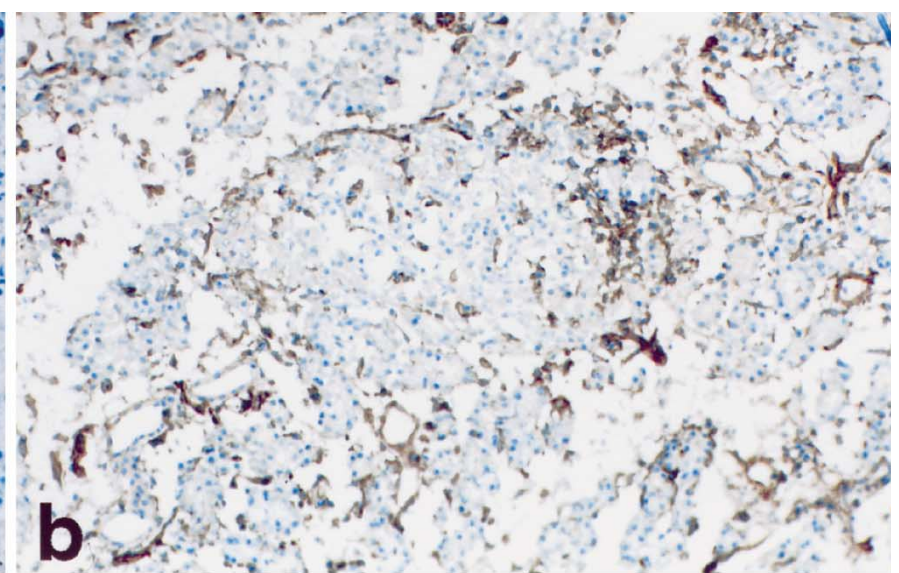

population of infiltrating $\mathrm{CD} 4^{+} \mathrm{T}$ cells. It is difficult to assess the numbers of $\mathrm{CD} 4^{+} \mathrm{T}$ cells, because in the rat, macrophages and $\mathrm{CD}^{+} \mathrm{T}$ cells share many of the same cell-surface markers, including CD4 [20].

\section{Discussion}

Our findings affirm that beta cell-autoreactive T cells and susceptibility to Type I diabetes are widely distributed in Class II $^{\mathrm{u}}$ haplotype rats. Autoimmunity is triggered in most Class $\mathrm{II}^{\mathrm{u}}$ strains by injections of the IFN- $\alpha$ inducer Poly IC. Similarly, spontaneous diabetes in the rat has thus far been reported only in the Class $\mathrm{II}^{\mathrm{u}} B B-D P / W o r$ [4-5] and LETL [6-7] strains. Susceptibility to diabetes in Class $\mathrm{II}^{\mathrm{u}}$, but not Class $\mathrm{II}^{\mathrm{a}}$ or Class $\mathrm{II}^{\mathrm{c}}$ rats, could be a consequence of the selective binding of the diabetogenic autoantigen to Class II ${ }^{\mathrm{u}}$ molecules. Our studies thus support the peptide affinity model for the Class II genetic contribution to Type I diabetes susceptibility. The allelic polymorphisms of diabetes-associated Class II molecules dictate binding of specific beta cell peptides that result in T cell activation and beta-cell destruction [21].

Not all Class $\mathrm{II}^{\mathrm{u}}$ haplotype rats developed insulitis and diabetes after Poly IC treatment, i.e. the $L O U$, $W A G$ and $W F$ rats. Thus, Class II binding of betacell peptide, islet cell Class I hyperexpression and increased leucocytic trafficking to the islets could be 

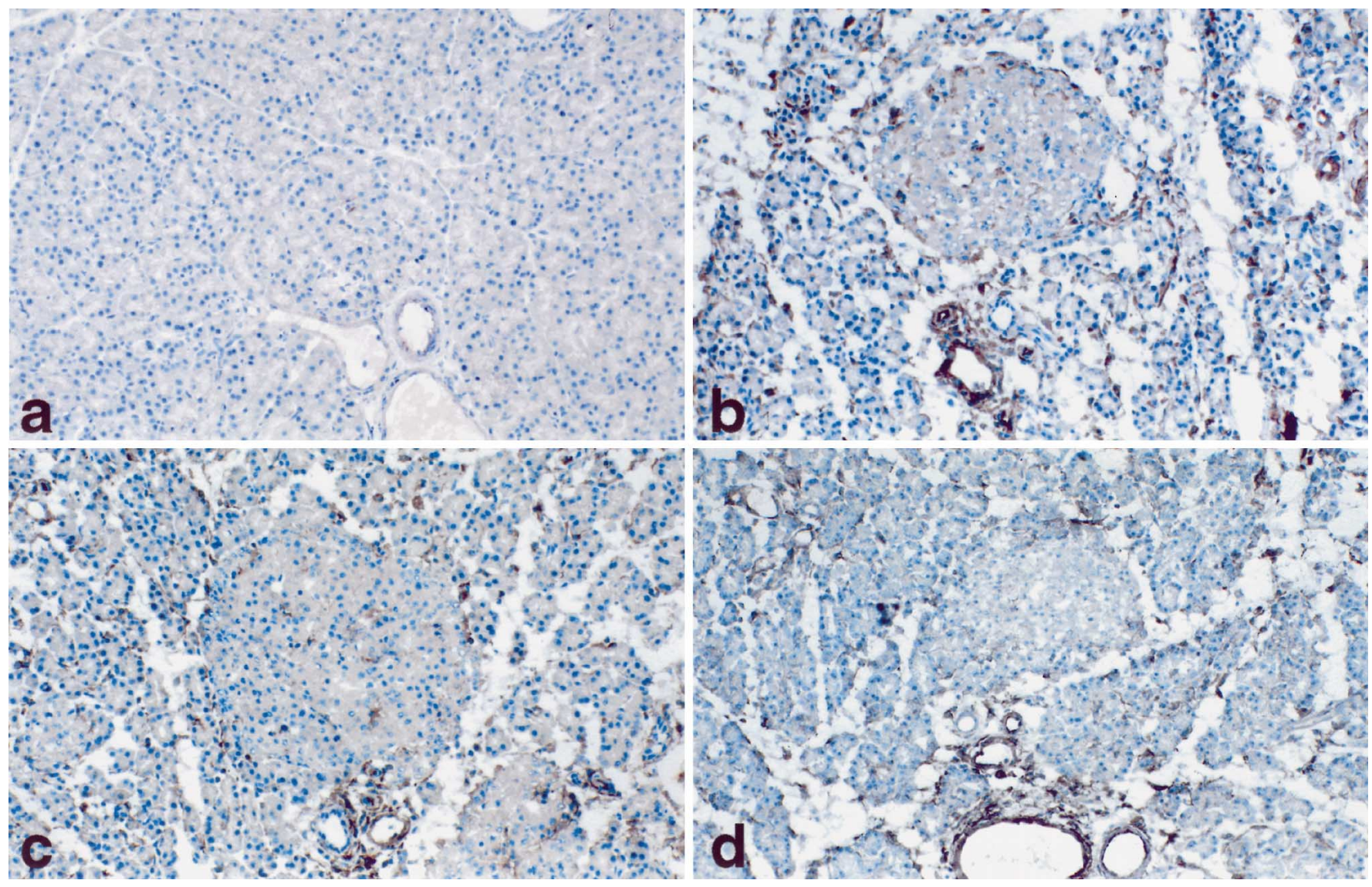

Fig.5 A-D. Poly IC-treatment induces endothelial VCAM-1 in both diabetes-susceptible and resistant rat strains. Illustrated are pancreatic sections stained by the immunoperoxidase method for VCAM-1. A A control $P V G^{u}$ rat injected with PBS for 8 days: endothelial VCAM-1 is not detected by immunostaining. B A diabetes-resistant $P V G^{c}$ rat injected with Poly IC for 8 days. C A diabetes-resistant $P V G . R 23$ rat injected with Poly IC for 8 days. D A diabetes-susceptible LEW1.WR1 rat treated with Poly IC for 8 days. The induction of endothelial VCAM-1 is not sufficient for the development of Type I diabetes

necessary, but are not sufficient, for the development of diabetes, even in the presence of susceptible Class II $^{\mathrm{u}}$ genes. The $L O U, W A G$ and $W F$ strains could possess a resistance allele at Iddm 3 [22] or other diabetes-resistance genes. Given that most Class II $^{\mathrm{u}}$ haplotype strains are susceptible to experimentally induced diabetes and the incidence of spontaneous disease is very small, diabetes-resistance genes must be of paramount importance in preventing autoimmunity.

Poly IC injections also induced the generation of diabetes-transferring spleen cells in most Class $\mathrm{II}^{\mathrm{u}}$ rats studied. This observation supports a pathogenic role for beta cell-autoreactive T cells in this model of autoimmune diabetes. The appearance of diabetestransferring cells in $W F$ and $W A G$ rats was unexpected, given that they are largely resistant to the diabe- togenic effects of Poly IC. Notably, T cells from $W F$ rats can transfer diabetes into syngeneic and BB-DP rats after sensitisation by passaging through $B B-D P$ recipients in vivo [23].

Poly IC treatment (and virus infections) could trigger autoimmunity by up regulating pancreatic endothelial adhesion receptors. Endothelial ICAM1 mediates the firm adhesion of Mac- $1^{+}$and LFA- $1^{+}$ leucocytes [24] and VCAM-1 mediates rolling and firm adhesion of $\alpha 4 / \beta 1$-expressing (VLA- $4^{+}$) leucocytes (all leucocyte cell types except granulocytes) [24]. Indeed, up regulation of these molecules was accompanied by a large influx of macrophage/monocyte/dendritic cell lineages and T cells into the pancreatic interstitium. The increased leucocytic trafficking could result in enhanced presentation of beta cell antigen to autoreactive T cells in situ. Note that pancreatic tissue obtained from newly diagnosed human Type I diabetic patients also exhibited endothelial ICAM-1 up regulation [25-27]. Finally, the presence of a predominantly $\mathrm{CD} 8^{+} \mathrm{T}$-cell infiltrate, coupled with islet cell Class I hyperexpression, suggests that cytotoxic $\mathrm{T}$ cells and Class I gene products are involved in the effector stages of beta-cell destruction.

Poly IC induces circulating IFN- $\alpha$ in $B B-D P / W o r$ and $W F$ rats [13], and this cytokine is believed to play a part in the pathogenesis of Type I diabetes. However, Poly IC increased serum IFN- $\alpha$ in $W F$ rats to concentrations equal to or greater than those 
found in $B B-D P$ rats and induced diabetes in the $B B$ $D P$, but not the $W F$ animals [13]. Interferon- $\alpha$ could be rate-limiting, however, if its cellular uptake or metabolism varies between strains. The role of IFN- $\alpha$ in other experimental models of Type I diabetes is contradictory. Transgenic beta-cell expression of IFN- $\alpha$ in mice can lead to insulitis and diabetes [28]. Islet expression of IFN- $\alpha$ precedes insulitis and diabetes in the $B B$ rat [29]. Injections of recombinant IFN- $\alpha$ inhibit diabetes development, however, in the NOD mouse [30]. In the case of Poly IC, a cascade of cytokines, including IFN- $\alpha$ could be responsible for the induction of diabetes in susceptible strains of rat.

As reported, Poly IC injections do not induce T cell lymphopenia [16, 31]. In our studies, Poly ICtreated rats, whether diabetic or not, had normal numbers of total $\mathrm{T}$ cells and increased numbers of $\mathrm{CD}^{+} \mathrm{T}$ cells in peripheral lymph nodes (data not shown). Thus, the diabetes-inducing effects of Poly IC cannot be ascribed to T-cell lymphopenia, a genetic susceptibility factor in the $B B-D P$ [22] but not in the lymphopenic non-diabetic $B B-D R /$ Edinburgh rat [32]. Of note is the recent report that $P V G . R T 1^{u}$ and $P V G . R T 1^{c}$ rats carrying the lymphopenia (lyp) gene do not develop diabetes ([33] and G. Butcher, personal communication). Clearly, lymphopenia and Class II $^{\mathrm{u}}$ alone are not permissive for the development of spontaneous disease, except in the case of the $B B$ $D P$ rat.

We conclude that the requirements for autoimmune diabetes induction in the rat include at least three interacting elements: RT1 Class $I I^{u}$ genes, a Tcell repertoire containing beta cell-autoreactive $\mathrm{T}$ cells (as assessed by the ability to adoptively transfer diabetes into naive recipients) and a triggering event which breaks tolerance through the local up regulation of endothelial adhesion receptors, thus increasing mononuclear cell trafficking to the pancreas. Other genetic factors might also however, be necessary, because $W A G$ and $W F$ rats rarely develop diabetes in response to Poly IC, even though they possess Class $\mathrm{II}^{\mathrm{u}}$ genes, beta-cell target molecules and diabetogenic T cells. Conversely, and perhaps more likely, resistance genes could be present in $W A G, W F$ and $L O U$ strains which prevent a diabetogenic response to Poly IC and other autoimmune stimuli. Finally, as double-stranded RNA is a potent inducer of diabetes in many rat strains, strong support is given to a role for Type I $(\alpha)$-IFN-inducing viruses in the pathogenesis of Type I diabetes.

Acknowledgements. This work was supported by the United States Public Health Service (USPHS) grant DK-19155 and USPHS contract N01-DK-2-2201 to A. A. Like. The contents of this publication are solely the responsibility of the authors and do not represent the official views of the NIH.

We wish to thank S. Costa, M. Glidden, P. Lanzilotti, A. Mascarenhas and S. Wang for outstanding technical support.

\section{References}

1. Noble J, Valdes A, Cook M, Klitz W, Thomson G, Erlich H (1996) The role of HLA Class II genes in insulin-dependent diabetes mellitus: Molecular analysis of 180 caucasian multiplex families. Am J Hum Genet 59: 1134-1148

2. Tisch R, McDevitt H (1996) Insulin-dependent diabetes mellitus. Cell 85: 291-297

3. Colle E, Guttmann R, Fuks A (1986) Insulin-dependent diabetes mellitus is associated with genes that map to the right of the Class I RT1.A locus of the major histocompatibility complex. Diabetes 35: 454-458

4. Nakhooda A, Like A, Chappel C, Murray F, Marliss E (1977) The spontaneously diabetic Wistar rat: metabolic and morphologic studies. Diabetes 26: 100-112

5. Colle E, Guttmann R, Seemayer T (1981) Spontaneous diabetes mellitus syndrome in the rat. I. Association with the major histocompatibility complex. J Exp Med 154: $1237-1242$

6. Kawano K, Hirashima T, Mori S, Saitoh Y, Kurosumi M, Natori T (1991) New inbred strain of Long-Evans Tokushima Lean Rats with IDDM without lymphopenia. Diabetes 40: 1375-1381

7. Yokoi N, Kanazawa M, Kitada K et al. (1997) A non-MHC locus essential for autoimmune Type I diabetes in the Komeda diabetes-prone rat. J Clin Invest 100: 2015-2021

8. Guberski D, Thomas V, Shek W et al. (1991) Induction of Type I diabetes by Kilham's Rat Virus in diabetes-resistant BB/Wor rats. Science 254: 1010-1013

9. Ellerman K, Richards C, Guberski D, Shek W, Like A (1996) Kilham Rat Virus triggers T cell-dependent autoimmune diabetes in multiple strains of rat. Diabetes 45 : $557-562$

10. Fowell D, Mason D (1993) Evidence that the T cell repertoire of normal rats contains cells with the potential to cause diabetes. Characterization of the $\mathrm{CD}^{+} \mathrm{T}$ cell subset that inhibits this autoimmune potential. J Exp Med 177: 627-636

11. Stumbles P, Penhale W (1993) IDDM in rats induced by thymectomy and irradiation. Diabetes 42: 571-578

12. Sen G, Lengyel P (1992) The interferon system. J Biol Chem 267: 5017-5020

13. Sobel D, Ewel C, Zeligs B, Abbassi V, Rossio J, Bellanti J (1994) Poly IC induction of $\alpha$-interferon in the diabetesprone BB and normal Wistar rats. Diabetes 43: 518-522

14. Tough D, Borrow P, Sprent J (1996) Induction of bystander T cell proliferation by viruses and Type I interferon in vivo. Science 272: 1947-1950

15. Ewel C, Sobel D, Zeligs B, Bellanti J (1992) Poly IC accelerates development of diabetes mellitus in diabetes-prone BB rat. Diabetes 41: 1016-1021

16. Sobel D, Newsome J, Ewel C et al. (1992) Poly IC induces development of diabetes mellitus in BB rat. Diabetes 41: 515-520

17. Sternthal E, Like A, Sarantis K, Braverman L (1981) Lymphocytic thyroiditis and diabetes in the $\mathrm{BB} / \mathrm{W}$ rat. Diabetes 30: 1058-1061

18. Ellerman K, Like A (1995) A major histocompatibility complex Class II restriction for BB/Wor diabetes-inducing T cells. J Exp Med 182: 923-930

19. Koevary S, Williams D, Williams R, Chick W (1985) Passive transfer of diabetes from BB/W to Wistar-Furth rats. J Clin Invest 75: 1904-1907

20. Jefferies W, Green J, Williams A (1985) Authentic T-helper CD4 (W3/25) antigen on rat peritoneal macrophages. J Exp Med 162: 117-127

21. Nepom G, Kwok W (1998) Molecular basis for HLA-DQ associations with IDDM. Diabetes 47: 1177-1184 
22. Jacob H, Pettersson A, Wilson D, Mao,Y Lernmark A, Lander E (1992) Genetic dissection of autoimmune Type I diabetes in the BB rat. Nat Genet 2: 56-60

23. Ramanathan S, Poussier P (1999) T cell reconstitution of $\mathrm{BB} / \mathrm{W}$ rats after the initiation of insulitis precipitates the onset of diabetes. J Immunol 162: 5134-5142

24. Brown E (1997) Adhesive interactions in the immune system. Trends Cell Biol 7: 289-295

25. Hanninen A, Jalkanen S, Salmi M, Toikkanen S, Nikolakaros G, Simell O (1992) Macrophages, T cell receptor usage, and endothelial cell activation in the pancreas at the onset of insulin-dependent diabetes mellitus. J Clin Invest 90: 1901-1910

26. Itoh N, Hanafusa T, Miyazaki A et al. (1993) Mononuclear cell infiltration and its relation to the expression of major histocompatibility complex antigens and adhesion molecules in pancreas biopsy specimens from newly diagnosed insulin-dependent diabetes mellitus patients. J Clin Invest 92: 2313-2322

27. Somoza N, Vargas F, Roura-Mir C et al. (1994) Pancreas in recent onset insulin-dependent diabetes mellitus. Changes in HLA, adhesion molecules and autoantigens, restricted $\mathrm{T}$ cell receptor $\mathrm{V} \beta$ usage, and cytokine profile. $\mathrm{J}$ Immunol 153: $1360-1377$

28. Stewart T, Hultgren B, Huang X, Pitts-Meek S, Hully J, MacLachlan N (1993) Induction of Type I diabetes by interferon- $\alpha$ in transgenic mice. Science 260: 1942-1946

29. Huang X, Hultgren B, Dybdal N, Stewart T (1994) Islet expression of interferon- $\alpha$ precedes diabetes in both the BB rat and streptozotocin-treated mice. Immunity 1: 469-478

30. Sobel D, Ahvazi B (1998) $\alpha$-interferon inhibits the development of diabetes in NOD mice. Diabetes 47: 1867-1872

31. Thomas V, Woda B, Handler E, Greiner D, Mordes J, Rossini A (1991) Altered expression of diabetes in BB/Wor rats by exposure to viral pathogens. Diabetes 40: 255-258

32. Joseph S, Diamond A, Smith W, Baird D, Butcher G (1993) BB-DR/Edinburgh: a lymphopenic, non-diabetic subline of BB rats. Immunology 78: 318-328

33. Hernandez-Hoyos G, Joseph S, Miller N, Butcher G (1999) The lymphopenia mutation of the $\mathrm{BB}$ rat causes inappropriate apoptosis of mature thymocytes. Eur J Immunol 29: 1832-1841 